\title{
The taphonomy of plant and livestock dung microfossils: an ethnoarchaeological and experimental approach
}

Article

Accepted Version

Portillo, M., Dudgeon, K., Allistone, G., Raeuf Aziz, K. and Matthews, W. (2021) The taphonomy of plant and livestock dung microfossils: an ethnoarchaeological and experimental approach. Environmental Archaeology, 26 (4). pp. 439-454. ISSN 1461-4103 doi:

https://doi.org/10.1080/14614103.2020.1800344 Available at https://centaur.reading.ac.uk/92270/

It is advisable to refer to the publisher's version if you intend to cite from the work. See Guidance on citing.

To link to this article DOI: http://dx.doi.org/10.1080/14614103.2020.1800344

Publisher: Taylor \& Francis

All outputs in CentAUR are protected by Intellectual Property Rights law, including copyright law. Copyright and IPR is retained by the creators or other copyright holders. Terms and conditions for use of this material are defined in the End User Agreement. 


\section{CentAUR}

Central Archive at the University of Reading

Reading's research outputs online 


\title{
The taphonomy of plant and livestock dung microfossils: an ethnoarchaeological and experimental approach
}

\author{
Marta Portillo ${ }^{1,2}$, Kate Dudgeon ${ }^{2}$, Georgia Allistone ${ }^{2}$, Kamal Raeuf Aziz ${ }^{3}$, Wendy \\ Matthews $^{2}$
}

${ }^{1}$ Department of Archaeology and Anthropology, Archaeology of Social Dynamics (2017SGR 995), Institució Milà i Fontanals (IMF), Spanish National Research Council (CSIC), Barcelona, Spain.mportillo@imf.csic.es

${ }^{2}$ Department of Archaeology, University of Reading, Reading, UK

3 Directorate of Antiquities and Heritage, Sulaimaniyah, Kurdistan Regional Government, Iraq

\begin{abstract}
This study examines the contribution of ethnoarchaeological and experimental research to interdisciplinary approaches on the identification and taphonomy of livestock dung. Ethnographic and experimental records provide comparative reference models on a range of taphonomic issues that are still understudied, such as variation in the type and preservation of plant and faecal microfossils that are excreted with dung and the effects of heating. The focus in the present study is on the taphonomy of ingested phytoliths and calcitic spherulites that originate in the digestive tracts of cattle, sheep and goat found in fresh modern dung pellets. The reported records are from the modern farming village of Bestansur, Iraqi Kurdistan. The experimental results show significant changes in microfossil composition and phytolith and spherulite stability and integrity, with increased melting of phytoliths and variations in morphotype composition (e.g. grass short cells appear less stable) from heating at temperatures around $800{ }^{\circ} \mathrm{C}$, whereas the spherulite darkening occurs within a range between $500-700{ }^{\circ} \mathrm{C}$, with a maximum production at $650^{\circ} \mathrm{C}$. This integrated approach illustrates the contribution of the muchneeded ethnographic and experimental records of animal dung to understanding of taphonomic issues, which are fundamental for the interpretation of this valuable microfossil material in archaeology.
\end{abstract}


Keywords: Livestock dung; ethnoarchaeology; taphonomy; experimental burning; phytoliths; dung spherulites.

\section{Introduction}

Livestock dung is increasingly being regarded as a valuable archaeological material as highlighted in major reviews by Shahack-Gross (2011) and Spengler (2019). Ethnographic approaches provide comparative reference datasets and models on several aspects affecting dung and coprolite production, composition, preservation and decay, as well as the range of ecological and anthropogenic aspects influencing these. Both opaline phytoliths and calcitic dung spherulites that originate in the digestive tracts of many animals, particularly ruminants, are increasingly being used as key microfossil data in ethnoarchaeological research (Friesem 2016, and references therein). Dung spherulites in particular are widely used as indicators of herbivore presence in caves and rockshelters (e.g. Brochier et al. 1992; Karkanas 2006; Delhon et al. 2008, 2020; Cabanes et al. 2009; Polo-Díaz et al. 2014, 2016), as well as within early farming and urban built environments (e.g. Matthews et al. 1996; Matthews 2005; Albert et al. 2008; Shahack-Gross and Finkelstein 2008; Portillo et al. 2009, 2019). The application of integrated analyses of dung spherulites and archaeobotanical evidence, enables investigation of a wide range of key issues and ecological strategies including animal management, foddering and grazing practices, seasonality, domestic activities and the use of dung as a secondary product such as manure, either in its organic form or after being burned, fuel, and temper for building (e.g. Kramer 1982; Miller 1984; Anderson and Ertuğ-Yaras 1998; Reddy 1999; Sillar 2000; Shahack-Gross et al. 2004). Further, interdisciplinary analytical methods in geoarchaeology, archaeobotany and biochemistry along with comparative geo-ethnoarchaeological data enable a robust identification and interpretation of dung remains and their archaeological significance (e.g. Vos et al. 2018; Portillo and Matthews 2020). The value of interdisciplinary approaches to studies of this important archaeological material has been recently evaluated from a local perspective, in the Konya Plain in Central Anatolia, in light of the emergence and spread of farming and highlighted its the role in the so-called 'secondary products revolution' (Portillo et al. 2020). 
Although most of the basic formation processes and taphonomy of both opaline phytoliths (Wilding and Drees 1974; Bartoli and Wilding 1980; Piperno 1988, 2006; Cabanes et al. 2011; Cabanes and Shahack-Gross 2015) and calcitic dung spherulites (Brochier et al. 1992; Canti 1998, 1999; Korstanje et al. 2002; Shahack-Gross 2011; Canti and Nicosia 2018) are well-understood, a range of specific taphonomic issues are still understudied, such as the variation in the digestibility, durability and seasonality of these plant and faecal microfossils that are excreted with dung, as well the impact of heating (burning) at different temperatures on their production, morphology and preservation. The understanding of these issues depends greatly on comparative reference ethnoarchaeological and experimental research (Brochier et al. 1992; Canti 1999; Korstanje et al. 2002; Shahack-Gross et al. 2003, 2004; Gur-Arieh et al. 2013; Portillo et al. 2014, 2017; Canti and Nicosia 2018; Égüez et al. 2018).

The work reported upon here represents the continuation of earlier ethnoarchaeological research in the foothills of the Zagros Mountains of Iraqi Kurdistan, in the framework of ongoing excavations at the Early Neolithic site of Bestansur (Figure 1). This study builds on previous ethnoarchaeological work on livestock management, seasonality, grazing, foddering, penning, manuring and domestic activities, as well as modern dung sampling from the modern farming village of Bestansur and its surroundings, which was followed by zoooarchaeological, isotope and soil analyses, in addition to integrated studies of phytoliths and calcitic dung spherulites for comparative purposes (Bendrey et al. 2013, 2016; Elliott et al. 2015). The current study expands the modern reference datasets and ethnographic records with additional modern dung materials and comparative experimental burning of cattle and ovicaprine dung assemblages, which are commonly used as resources for fuel, as illustrated ethnographically (e.g. Kramer 1982; Miller 1984; Anderson and Ertug-Yaras 1998; Reddy 1999; Zapata et al. 2003). The aim of this study is to address the taphonomy of both lines of microfossil evidence, phytoliths and dung spherulites, based on the comparison between cattle and sheep/goat dung assemblages burnt at different combustion conditions across a range of temperatures under laboratory-controlled experiments. The aim in creation of these comparative datasets is to provide insights into taphonomic issues related to microfossil preservation after heating (burning), and their significance in the archaeological record and to identify diagnostic indicators of these, such as the melting of phytoliths displaying opaque bubbling surfaces widely 
reported archaeologically and ethnoarchaeologically (e.g. Macphail and Cruise 2001; Matthews 2010, 2016; Gur-Arieh et al. 2013, 2014; Portillo et al. 2017; Vrydaghs et al. 2017), and the occurrence of darkened or opaque spherulites, displaying from slightly transparent through to completely opaque morphologies (e.g. Brochier 1993, 2002; Polo-Díaz et al. 2014, 2016; Canti and Nicosia 2018). The results are contrasted and compared to previous experimental studies on the morphological alterations and phytolith stability as a result of heating of several modern plant species (Runge 1998; Brochier 2002; Wu et al. 2012, 2014), on the solubility of phytolith assemblages on modern plants (Cabanes et al. 2011; Cabanes and Shahack-Gross 2015), and on the occurrence of darkened spherulites from sheep and goat fresh dung pellets (Canti and Nicosia 2018). The main objective is to contribute to better understanding of the ways in which heating affects phytolith morphotype and dung spherulite composition and the integrity of both microfossil records, in order to evaluate their implications for the identification and interpretation of dung assemblages in the archaeological record.

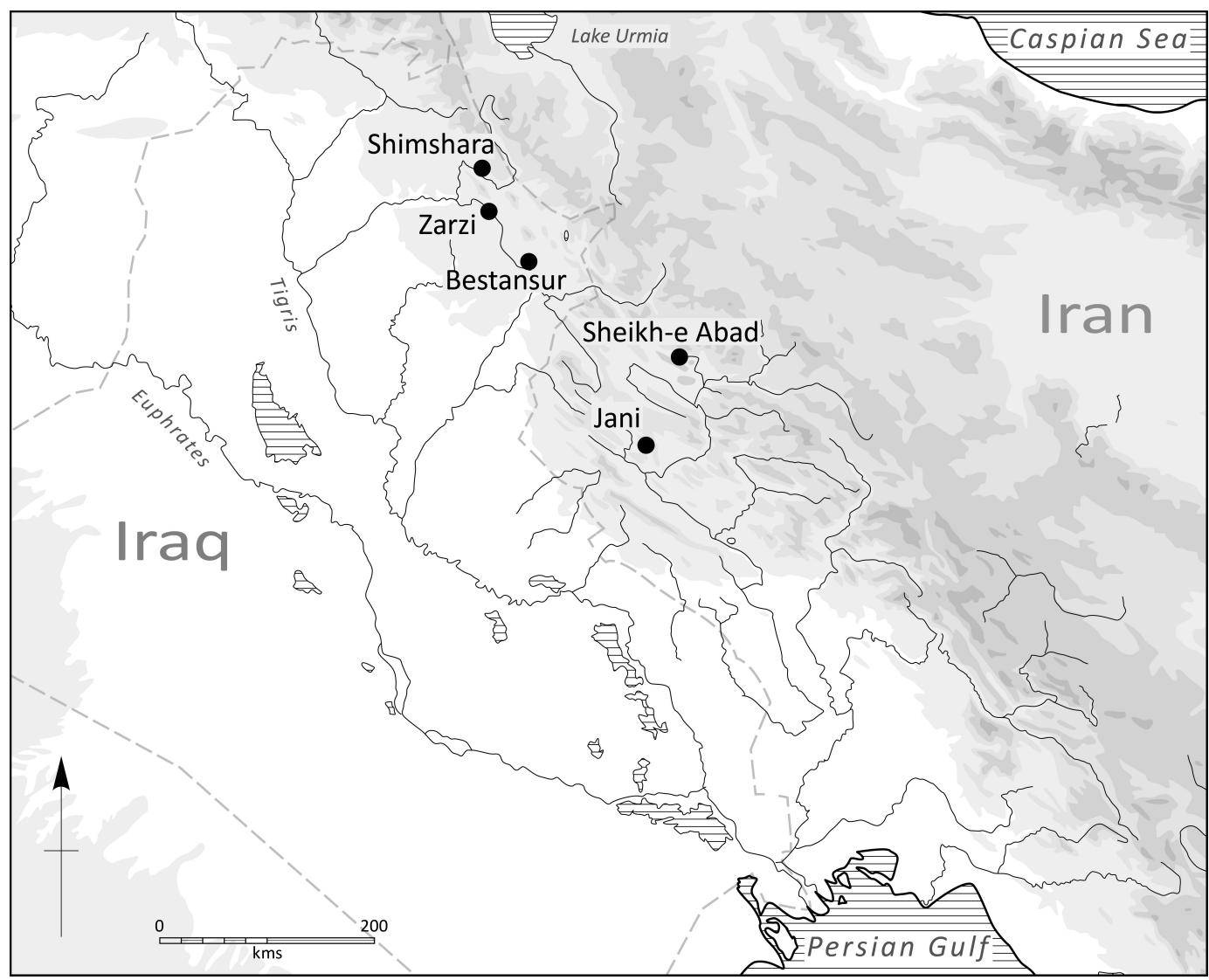

Figure 1: Map showing the general location of Bestansur and other sites investigated within the Central Zagros Archaeological Project (CZAP). 


\subsection{Research area}

The research area on the western edge of the Shahrizor Plain in Iraqi Kurdistan has a semi-arid climate with a strong continental component, defined by cold and wet winters, and warm and dry summers (Maran and Stevanovic 2009). The area receives ca. 375-724 $\mathrm{mm}$ of annual rain on average characterised by a high annual variability, with rainfall concentrated between the middle of October and the beginning of May. The variability in the topography and elevation of the Zagros mountains, with an average height of about 2,400 m, influences this considerable diversity in rainfall with decreased precipitation rates from the mountains of the northeast to the desert-steppe of the southwest (Maran and Stevanovic 2009).

The modern settlement of Bestansur is a farming village of approximately 50 households (Elliott et al. 2015), situated at ca. $550 \mathrm{~m}$ above sea level, about $33 \mathrm{~km}$ to the southeast of Sulaimaniyah city and $c a .700 \mathrm{~m}$ north of the Neolithic mound with the same name. The archaeological site of Bestansur, included on the UNESCO World Heritage Tentative List, is an early Neolithic settlement (7600-7100 BC) characterised by rectilinear pisé and mudbrick architecture. The settlement was located close to a major spring ( $c a .400 \mathrm{~m}$ north of the archaeological mound) and deposits are subject to a fluctuating water table in addition to regular irrigation in the cultivated fields surrounding the mound itself. For more information on the site see Matthews et al. 2016, 2019, and 2020. Bestansur is located in an alluvial plain that supports modern arable farming (Saed Ali 2008). The economic production of the area at the present day is based on cereal agriculture, although river catchment areas in the alluvial plain also allow horticultural crops, in addition to livestock farming of sheep, goat, and cattle (Elliott et al. 2015).

\section{Materials and methods}

\subsection{Ethnoarchaeological fieldwork and modern material sampling}

Extensive ethnographic research has previously been conducted in the Zagros region of central western Iran during the 1970s and early 1980s, and centered on a range of issues including pastoral nomadism, domestic architecture, and technology (Hole 
1978, Kramer 1979, 1982; Watson 1979). This study builds on previous work to address modern management of livestock within the local landscape and to elucidate links between animal and plant resources at the modern village of Bestansur (Bendrey et al. 2013; Elliott et al. 2015). The present work enlarges the study and focuses in particular on dung exploitation, management and storage, as well as the secondary use of dung as fuel with the sampling of new materials and ethnographic observations from two additional households from the village. Fieldwork was carried out during the spring of 2017 (beginning of May) and comprised ethnographic observations, informal interviews, and sampling of materials from households, as well as across pasture grounds from the vicinity and the lower limestone foothills (Figure 2). These included photography and informal interviews with three families using a questionnaire with full permission, following ethical protocols. The modern materials and activity areas sampled within the households included animal enclosures, storage facilities, activity open areas, and fire installations. Livestock dung material is readily available in the village in constructed in-door penning spaces as well as in open-air animal enclosures. The aim in collecting modern dung remains was to study different grazing and foddering regimes. This study focused on fresh dung samples primarily from ruminants (cattle and sheep/goat), as these are prolific producers of dung spherulites (Canti 1999). The dung samples used in the experimental work reported below come from animals kept together in an open-air enclosure displaying a grass-rich diet based on grazing and supplementary fodder for cattle, primarily barley chaff from the household's own production.
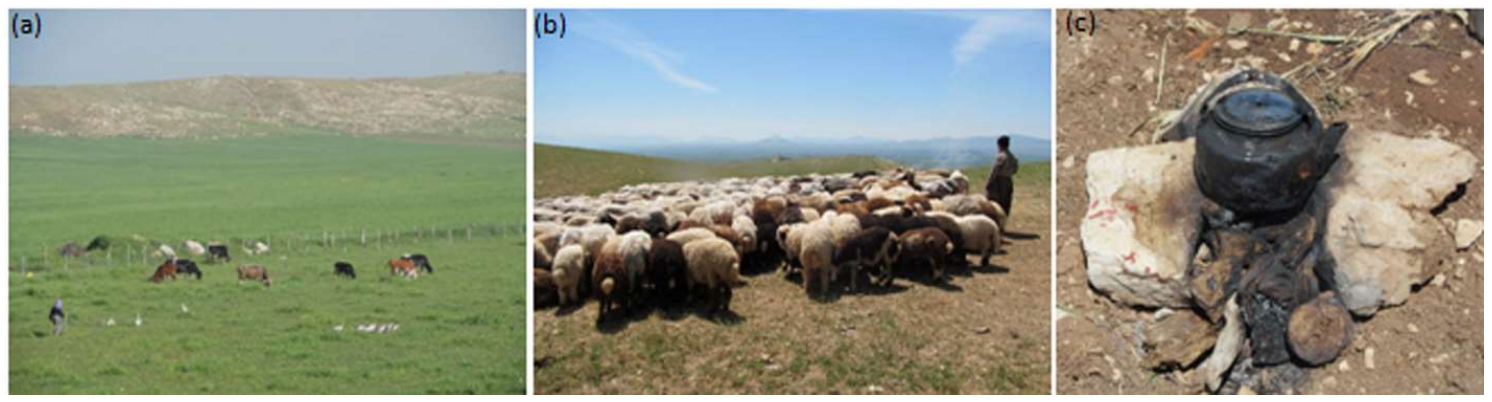

Figure 2: Livestock management and dung use as fuel at the study area, spring 2017. (a) Daily cattle grazing within the village of Bestansur surroundings; (b) sheep and goat grazers in the lower limestone hills; (c) cattle dung as fuel source for boiling water for tea. 


\subsection{Burning experiments}

Modern dung samples from cow and sheep/goat were selected for burning experiments under laboratory-controlled conditions. All samples were dried at $c a .70{ }^{\circ} \mathrm{C}$ in the field laboratory. Samples were weighed and then heated in a furnace oven at the School of Archaeology, Geography and Environmental Science, University of Reading for four hours at temperatures between 400 and $900{ }^{\circ} \mathrm{C}$, at intervals of 50 or $100{ }^{\circ} \mathrm{C}$. The final sample weights were also recorded. The duration of the experimental burning was set at four hours as this is the standard followed in dry-ashing methods in oxidation conditions for phytolith and spherulites analyses from modern fresh dung (e.g. ShahackGross et al. 2003; Albert et al. 2008; Tsartsidou et al. 2008; Portillo et al. 2012, 2014; Gur-Arieh, et al. 2013), and is arguably the approximate duration of heating within domestic dung-fuelled closed combustion installations (e.g. Portillo et al. 2017).

The methods used to produce darkened spherulites were similar to those proposed by Canti and Nicosia (2018) to avoid overheating within the furnace oven and maintaining reducing conditions by creating a partially reduced atmosphere within the sample containers. To evaluate the reproducibility of the methodology, burning experiments were replicated four times, in both oxidising and reducing conditions.

\subsection{Phytolith analyses}

Phytolith analyses followed the methods of Katz et al. (2010). A weighed aliquot of $40 \mathrm{mg}$ of ashed material was treated with $50 \mu \mathrm{l}$ of a volume solution of $6 \mathrm{~N} \mathrm{HCl}$. Phytoliths were concentrated with $450 \mu 12.4 \mathrm{~g} / \mathrm{ml}$ of sodium polytungstate solution [Na6(H2W12O40)]. Aliquots of $50 \mu 1$ of material were mounted on microscope slides using $24 \times 24$ cover slips. Phytoliths were examined in random fields at $\times 200$ and $\times 400$ magnification using a Leica DMEP optical microscope. A minimum of 400 phytoliths with diagnostic morphologies were counted following the standards of Katz et al. (2010). Each sample was counted in triplicate. Photomicrographs were captured with a Leica DFC420 camera. Morphological identification was based on modern plant reference collections and standard literature (Twiss et al. 1969; Brown 1984; Piperno 1988, 2006; Rosen 1992; Twiss 1992; Mulholland and Rapp 1992; Albert and Weiner 2001; Tsartsidou et al. 2007; Albert et al. 2008, 2016; Portillo et al. 2014). The terms 
used to describe phytolith morphologies follow the standards of the International Code for Phytolith Nomenclature - ICPN 2.0 (Neumann et al. 2019).

\subsection{Dung spherulite analysis}

Similarly to the phytolith analyses, samples of $40 \mathrm{mg}$ of ashed material were treated with $450 \mu 12.4 \mathrm{~g} / \mathrm{ml}$ of sodium polytungstate solution. Microscope slides were also mounted with aliquots of $50 \mu \mathrm{l}$ of sample. The initial weight in rich-spherulite samples was of around $20 \mathrm{mg}$ in order to avoid microfossil overloading. A minimum of 1000 spherulites were counted from each sample whenever possible at $\times 200$ magnification (with occasional examination at $\times 400$ ) under an optical microscope with cross-polarized light (XPL). Samples from both oxidation and reduction conditions were counted in triplicate.

Samples were then compared to phytolith and spherulite reference ethnoarchaeological datasets of modern livestock dung remains and dung fuels that have followed a similar quantitative approach (Tsartsidou et al. 2008; Portillo et al. 2012, 2014, 2017; Gur-Arieh et al. 2013; Portillo and Matthews 2020).

\section{Results and discussion}

\subsection{Ethnographic observations}

The ethnoarchaeological study was conducted in order to provide key information on parameters that influence the production, availability and composition of animal dung such as environment, animal ecology, grazing patterns and animal species, penning and on the origin of the dung selected for this experimental analysis, as reported in section 2.1 and previous research (Tables 9 to 12 in Elliott et al. 2015).

Despite the modern irrigation system, widely used in agricultural production of the present day, the village of Bestansur maintains a range of aspects of traditional ways of life. The results from informants discussing past and current farming activities have provided further insights into the continuity and change of practices through time (Elliott et al. 2015). The main change over the last years was the construction of the road heading from Arbat travelling east over the border into Iran, which divides the landscape into two zones: i) the zone around the modern village and the Neolithic 
mound within the river catchment area and the agricultural alluvial floodplain; and ii) the zone furthest from the village comprising the limestone foothills (Elliott et al. 2015), which is now less accessible, as a consequence of the dangers presented by fast moving traffic on this major road leading to the high Zagros.

The current study comprised one of the previously interviewed households (Table 9 in Elliott et al. 2015), and focused on two new households from the second zone furthest from the village in the foothills. The new informants further confirmed the variation in seasonal land use and herding practices observed in previous studies, characterised by temporary penning of sheep/goat in fallow agricultural fields during the warm and dry months and grazing in the hills particularly in the spring, whereas cattle are generally kept in enclosures within the village or grazed on the common and mostly feed within or close to the household (Figure 2a-b). Many of the houses comprise a main building and a garden where fruit and vegetables are cultivated for daily intake and for animal fodder. Herds provide milk, yogurt, cheese, wool, and particularly meat for consumption at the local and the regional level. This research has shown that today livestock provide a regular and predictable production of dung material as a source of manure, whereas the use of dung as fuel for cooking and heating is almost absent in this region since the introduction of gas in the 1980s. However, cattle dung is still used as fuel for cooking and boiling water among herders grazing sheep and goats in pasture grounds in the foothills (Figure 2c). Interestingly, the use of dung as fuel has been reported in the Early Neolithic site of Bestansur, by the identification of spherulitic ashes within combustion features such as ovens and hearths, as well as in rake-outs or refuse deposits from building areas (Matthews 2016; Matthews et al. 2020b), as in many other early farming built environments across the Near East (e.g. Matthews 2010, 2016; Portillo et al. 2020, and references therein). In light of these early and long-term uses of dung as a renewable source of manure and fuel, and the scarcity of ethnographical modern dung fuel materials from the site area, we present below experimental burning microfossil records obtained under laboratorycontrolled conditions in order to investigate microfossil taphonomy and the implications for interpreting the archaeological record.

\subsection{Phytolith results and taphonomic considerations}


A major aim of these experiments was to assess changes in phytolith morphotype abundances and whether certain morphologies may become less stable or susceptible to degradation in their shapes and surfaces than others under combustion, as the manner in which heating affects phytolith composition is poorly understood.

The quantitative results are presented as total numbers of phytoliths counted as well as average numbers in $1 \mathrm{~g}$ of ashed dung material (Table 1). The relative abundances of the main consistent morphotypes identified in the whole assemblages are expressed as averages of percentages of the total identifiable phytoliths in Table 2 .

\begin{tabular}{llllll}
\hline $\begin{array}{l}\text { Material/ } \\
\text { temperature } \\
\left({ }^{\circ} \mathbf{C}\right)\end{array}$ & $\begin{array}{l}\text { Total n. } \\
\text { phytoliths } \\
\text { counted }\end{array}$ & $\begin{array}{l}\text { Average n. } \\
\text { phytoliths } \mathbf{~ g ~ o f ~} \\
\text { ashed dung } \\
\text { (million) }\end{array}$ & $\begin{array}{l}\text { Average } \\
\text { weathered } \\
\text { morphotypes } \\
\mathbf{( \% )}\end{array}$ & $\begin{array}{l}\text { Average } \\
\text { melted } \\
\text { morphotypes } \\
(\%)\end{array}$ & $\begin{array}{l}\text { Average } \\
\text { multicelled } \\
\text { phytoliths } \\
(\%)\end{array}$ \\
\hline C-400 & 715 & 17.2 & 2.8 & 0 & 13.4 \\
O-400 & 698 & 16.3 & 2.5 & 0 & 15.9 \\
C-500 & 724 & 17.7 & 4.4 & 0 & 16.5 \\
O-500 & 763 & 17.4 & 2.2 & 0 & 9.9 \\
C-550 & 714 & 12.1 & 5.7 & 0.6 & 16.4 \\
O-550 & 694 & 15.6 & 1.9 & 0.4 & 17.9 \\
C-600 & 671 & 20.7 & 3.4 & 0.3 & 12.2 \\
O-600 & 656 & 13.4 & 3 & 0.3 & 15.1 \\
C-650 & 783 & 14.2 & 5.7 & 1 & 13 \\
O-650 & 740 & 12.1 & 3.5 & 1.2 & 13.5 \\
C-700 & 685 & 11.5 & 5.8 & 0.8 & 12.8 \\
O-700 & 727 & 14.1 & 4.4 & 1.4 & 13.7 \\
C-750 & 799 & 16.4 & 2.2 & 1.5 & 14.7 \\
O-750 & 768 & 7.9 & 1.7 & 2.4 & 13.2 \\
C-800 & 745 & 4.7 & 6.1 & 1.3 & 16.4 \\
O-800 & 723 & 2.7 & 8.4 & 17.4 & 16.4 \\
C-900 & 464 & 1.1 & 5.5 & 16.5 & 18.4 \\
O-900 & 486 & 1.2 & 8.9 & 25.8 & 8.9 \\
\hline
\end{tabular}

Table 1: Main quantitative phytolith results obtained from experimental dung samples with indication of animal producer and burning temperatures. C: cow, O: ovicaprine (sheep/goat).

The so-called weathered morphotypes (Table 1) refer to unidentifiable phytoliths displaying pitted surfaces and irregular shapes that may derive from pre-depositional, 
depositional and post-depositional weathering and alteration by dissolution for example (Cabanes et al. 2011). Although the presence or absence of weathered morphotypes is readily used as an indicator of the state of preservation of phytolith assemblages, it has been argued that not all are the product of weathering and taphonomy and that some may also relate to incomplete silicification of plant cells (Cabanes et al. 2011). In these experimental assemblages of dung it is recognised that their morphology and alteration/preservation may also be affected by either the extent of silicification of plant cells ingested as well as their solubility during digestion and excretion and variation in gut and bowel conditions in addition to laboratory chemical extraction, rather than heating.

\begin{tabular}{llllllllllll}
\hline $\begin{array}{l}\text { Material/ } \\
\text { temperature } \\
\text { ( } \mathbf{C} \text { C) }\end{array}$ & \% ACU & \% BUL & $\begin{array}{l}\text { \% ELO } \\
\text { DEN }\end{array}$ & $\begin{array}{l}\text { \% ELO } \\
\text { DENT }\end{array}$ & $\begin{array}{l}\text { \% ELO } \\
\text { ENT }\end{array}$ & $\begin{array}{l}\text { \% ELO } \\
\text { SIN }\end{array}$ & $\begin{array}{l}\text { \% MC } \\
\text { DEN }\end{array}$ & $\begin{array}{l}\text { \% MC } \\
\text { DENT }\end{array}$ & $\begin{array}{l}\text { \% MC } \\
\text { ENT }\end{array}$ & $\begin{array}{l}\text { \% } \\
\text { PAP }\end{array}$ & \% SHC \\
\hline C-400 & 8 & 0.3 & 1.9 & 1.6 & 2.4 & 5.8 & 3.3 & 2.1 & 7.2 & 6.5 & 36.8 \\
O-400 & 9,7 & 0.1 & 0.3 & 0.7 & $2 . .1$ & 6.6 & 5 & 1.7 & 8.1 & 7.3 & 30.5 \\
C-500 & 5,8 & 0.1 & 3.3 & 0.5 & 1.8 & 5.1 & 3.7 & 1.1 & 9.6 & 4.7 & 41.4 \\
O-500 & 8,9 & 0.6 & 1.8 & 0.7 & 2.2 & 8.4 & 2.3 & 0.7 & 6.6 & 5.2 & 33 \\
C-550 & 9,6 & 0 & 1.7 & 1.3 & 1.6 & 4 & 3.8 & 1.6 & 9.5 & 6.5 & 37.9 \\
O-550 & 6,1 & 0.5 & 1.7 & 0.6 & 2.9 & 7.7 & 5.8 & 2.2 & 8.8 & 4.2 & 31.5 \\
C-600 & 10,7 & 0.1 & 2 & 0.9 & 1.7 & 5.3 & 2.7 & 0.6 & 7.7 & 7.6 & 44.4 \\
O-600 & 4,1 & 0.6 & 0.8 & 0.2 & 2.3 & 8.1 & 5.1 & 1.3 & 7.5 & 4.1 & 35.5 \\
C-650 & 4,4 & 0.3 & 2.2 & 0.9 & 2 & 6.2 & 3.9 & 0.8 & 7.9 & 2.2 & 37.3 \\
O-650 & 5,9 & 0.3 & 1.7 & 0.4 & 2 & 8.3 & 5.9 & 1.6 & 5.1 & 3.5 & 37.4 \\
C-700 & 8,8 & 0.3 & 3.5 & 0.8 & 1.9 & 5.5 & 3.3 & 0.8 & 7.5 & 5.8 & 37.3 \\
O-700 & 9,1 & 0.1 & 0.3 & 0.3 & 2.3 & 6.4 & 5.5 & 1.2 & 6.4 & 5 & 34.8 \\
C-750 & 6,4 & 0.3 & 0.6 & 0.5 & 1.5 & 2.9 & 10.5 & 0.6 & 3.4 & 3.4 & 47.3 \\
O-750 & 6,7 & 2.2 & 8.7 & 2.6 & 2.9 & 8.2 & 8.8 & 0.9 & 3.5 & 2.6 & 28.5 \\
C-800 & 11,1 & 0.6 & 2.9 & 1.1 & 0.8 & 5.5 & 4.8 & 2 & 6.6 & 6.5 & 32.3 \\
O-800 & 7,1 & 0.6 & 0.2 & 0.2 & 0.7 & 5.7 & 5 & 1.7 & 7 & 1.8 & 16.1 \\
C-900 & 11,7 & 0.8 & 3.2 & 1 & 1.1 & 3.6 & 7.6 & 0.9 & 9.3 & 5.2 & 16.6 \\
O-900 & 8,6 & 0.3 & 3.4 & 2.8 & 0.5 & 4.8 & 2.1 & 0.2 & 5.7 & 2.3 & 14.4 \\
\hline
\end{tabular}

Table 2: Average percentages of main morphologies from phytolith samples according to the ICPN 2.0 morphotypes (Neumann et al. 2019). ACU= Epidermal appendage acute bulbosus (acicular/unciform hair cell, ICPN 1.0 in Madella et al. 2005), BUL= Bulliform flabellate (cuneiform bulliform cell), ELO DEN= Elongate dendritic, ELO DENT= Elongate dentate (elongate echinate long cell), ELO ENT= Elongate entire (psilate), ELO SIN= Elongate sinuate, MC DEN $=$ Multicellular structure of elongate dendritics (silica skeleton with dendritic/papillate/short cells/stomata), MC DENT= Multicellular structure of elongate dentates (silica skeleton with dentate/papillate/short cells), MC ENT= Multicellular structure of elongate entire (psilate), $\mathrm{PAP}=$ papillate (papillae), $\mathrm{SHC}=$ Short cell (rondel/bilobate/polylobate). 

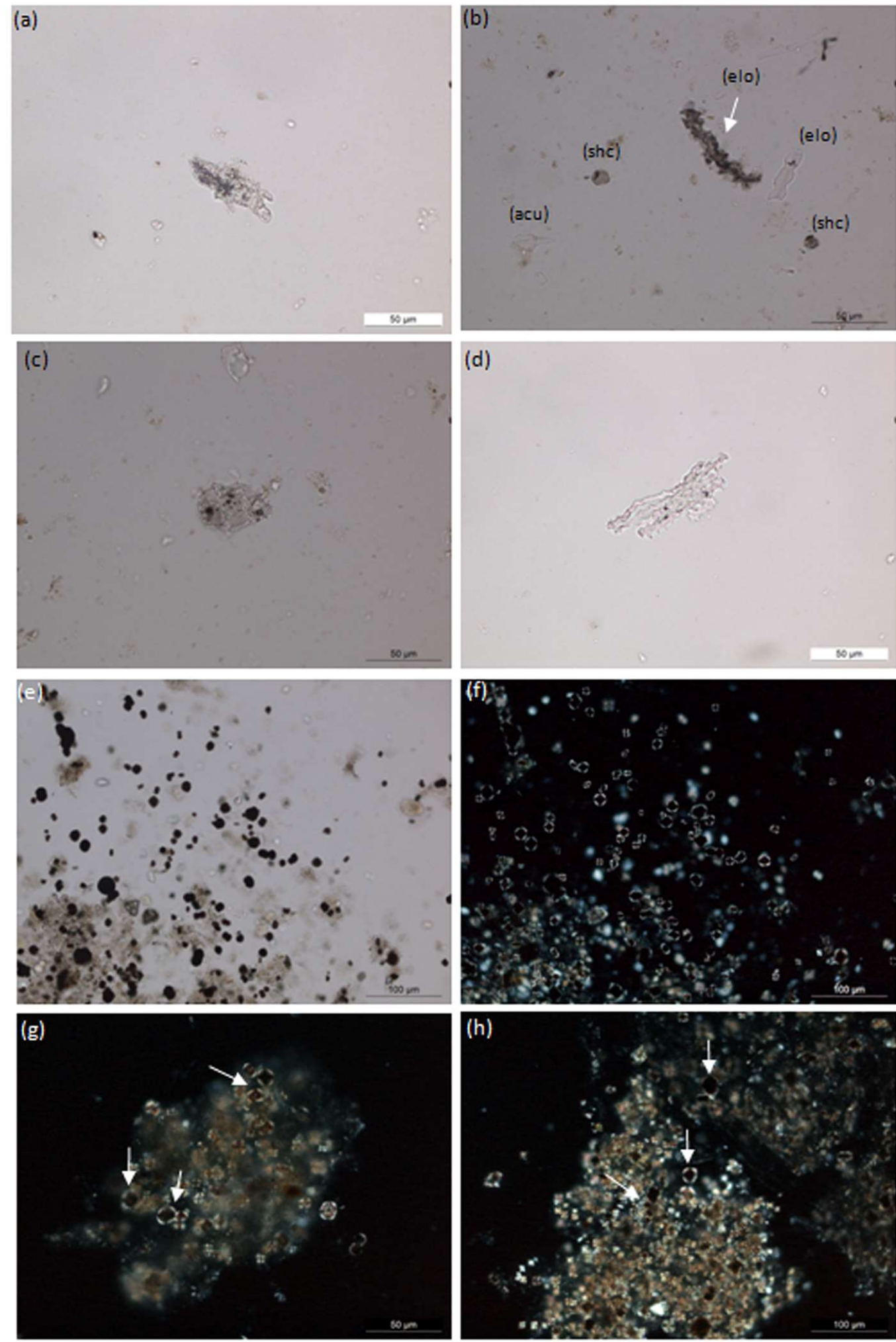

Figure 3: Photomicrographs of phytoliths and dung spherulites identified in the samples $(200 \times$ or 400×). (a) melted non-identifiable phytolith morphotype, sample O-900; (b) rondel short cells (shc), elongates (elo) and acute phytoliths (acu) (arrow showing a completely opaque partially melted dendritic), sample O-650; (c) papillates displaying slightly bubble protrusions, sample C-650; (d) multicelled elongate dendritics, sample C-900; (e) dung spherulites at PPL, sample O-650; (f) dung spherulites, mostly darkened, the same view at XPL, sample O-650; (g-h) clusters of dung spherulites (only few darkened, arrows), sample O-550. 
Melted morphotypes refer to phytoliths that are deformed and display alterations due to heating that range from slightly bubbled surfaces to completely opaque vesicular or sinuous morphologies which can no longer be assigned to specific morphotypes (Figure 3a). Both partially weathered and melted phytoliths that were still recognisable were then attributed to specific morphotypes (Figure $3 b$ ).

Phytolith quantities recovered range between 1.1 and 20.7 million per $1 \mathrm{~g}$ of ashed dung (Table 1). The cow samples contained more phytoliths than sheep/goat dung pellets in most of the assemblages. This is consistent with previously reported quantitative phytolith records from dung remains collected from other households in Bestansur (Table 12 in Elliott et al. 2015). The results show a reduction in phytolith numbers per $1 \mathrm{~g}$ of ashed dung, particularly in assemblages burnt at temperatures of 800 ${ }^{\circ} \mathrm{C}$ and higher, in both cow and sheep/goat samples. The relative abundances of weathered morphotypes are generally low across the assemblages through all temperature ranges (between 1.7 and 8.4\%). Multicelled forms occur in all samples (from 8.9 to $18.4 \%$ ), and variations in numbers are also not associated with temperature increases (Table 1). By contrast, a decrease in phytolith numbers overlaps with increased proportions of melted phytoliths particularly in the range of $c a .800-900{ }^{\circ} \mathrm{C}$ and higher, which accounts for up to $25.8 \%$ of all the counted morphotypes in sample O-900 (Figure 4).

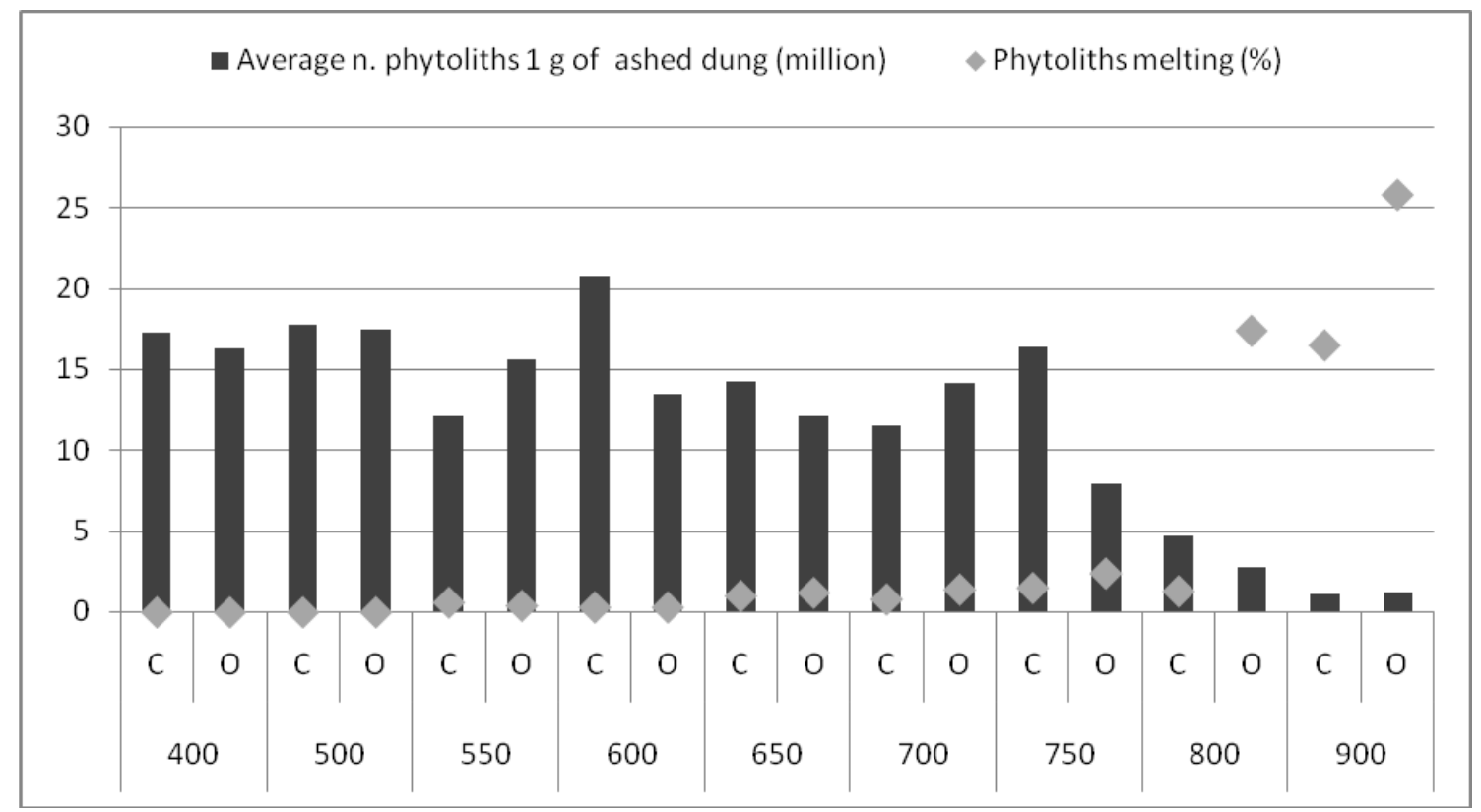

Figure 4: Plot showing absolute average concentrations of phytolith numbers and percentages of non-identifiable melted phytolith morphotypes. 
Previous experimental laboratory studies reported morphologic alterations occurring above $600{ }^{\circ} \mathrm{C}$, pointing to a phytolith melting point between the range between 900 and $1100{ }^{\circ} \mathrm{C}$ (Runge 1998; Brochier 2002, and references therein). Although silica has a melting point above $1700{ }^{\circ} \mathrm{C}$, the presence of components such as alkaline salts can act as fluxing agents that reduce melting point, and plant silica has been reported to melt at temperatures around $850{ }^{\circ} \mathrm{C}$ (Canti 2003). Other significant changes in the alteration of the morphology and the stability of phytoliths have also been identified and classified in a study of the effect of heating on several modern plant species, including the leaves and the husk of rice (Oryza sativa L.) and the leaves of white mulberry (Morus alba L.) and Than tree (Pteroceltis tatarinowii M.), an endangered relict tree endemic to China (Wu et al. 2012, 2014). The phytoliths from the leaves of both $P$. tatarinowii and M. alba preserved their morphology well and lose their characteristic morphologies at $700{ }^{\circ} \mathrm{C}$ (see Figures 2 and 3 in $\mathrm{Wu}$ et al. 2012), but become completely altered at $800{ }^{\circ} \mathrm{C}$. In contrast, little changes in rice leaf phytoliths were noted at $800{ }^{\circ} \mathrm{C}$, but were significantly altered when the heating exceeded $900^{\circ} \mathrm{C}$; whereas rice husk morphotypes resisted at temperatures as high as $1100{ }^{\circ} \mathrm{C}$ (Figures 4 and 5 in $\mathrm{Wu}$ et al. 2012). These differences were argued to relate to variation in their chemistry, with increased stability due to dominant flux components such as potassium, magnesium and calcium in the phytoliths (Wu et al. 2014).

Although partial melting is common in many of our experimental assemblages, most of the non-identifiable completely melted phytoliths occurred in the range of $c a$. $800-900{ }^{\circ} \mathrm{C}$ with a maximum $c a .25 \%$ among the sheep/goat pellets. Our experimental dung assemblages were derived from animals with a late spring grazing grass-rich diet supplemented with cereal straw foddering in the case of cattle. Most of the phytoliths derive from the leaves and stems of grasses, as well as from the inflorescences to a lesser extent. Most of the phytoliths from these assemblages were only partially affected by melting, and were still recognisable and morphologically identifiable at around 900 ${ }^{\circ} \mathrm{C}$. As flux agents are a significant parameter in reducing the melting point of plant silica (Canti 2003; Wu et al. 2012, 2014), the production of melted silica phytolith characteristics and morphotypes at these comparatively low temperatures of $900{ }^{\circ} \mathrm{C}$ may suggest that fluxing elements are common in the grass-dominated dietary composition of these animals. 
Further experimental work is needed to determine phytolith stability in herbivorous dicotyledonous-based diets. These are expected to produce a higher melting index given that leafy components are less stable with increased heating, and the effects of higher heating temperatures between 950 and $1100{ }^{\circ} \mathrm{C}$ in experimental situations. However, the latter is not particularly relevant to the current study as this range of temperatures is not expected to occur in the combustion of dung materials. Experimentally burned cattle and sheep dung in open-air conditions often do not reach more than $630{ }^{\circ} \mathrm{C}$ (Shahack-Gross et al. 2005; Shahack-Gross 2011), although higher temperatures are expected within dung-fueled closed combustion installations (e.g. Sillar 2000; Gur-Arieh et al. 2013; Portillo et al. 2014). Partial melting of phytoliths has been reported within sheep/goat dung fuel remains from traditional mud tannur type ovens (known as tabouna in northern Tunisia) where the maximum temperatures recorded were around $850^{\circ} \mathrm{C}$ (Portillo et al. 2017).

Although variations in the species of animal producers may affect dietary habits, as cows are usually less prone to browsing on the leaves of shrubs and trees than sheep and particularly goats, some patterns in the relative abundance of the main phytolith morphotypes were observable in the experimental and ethnographic datasets, that in this case-study may relate also to human manipulation of fodder (supplementary barley straw for cows) (Figures 5 and 6). Grass short cells are by far the most dominant, representing around $30-40 \%$ or more in most of the assemblages in this study, although they decrease significantly in proportion to other morphotypes from $c a .800-900{ }^{\circ} \mathrm{C}$ ( $c a$. 14-16\%, Table 2). These short cell morphologies comprise mostly rondels, although bilobates and polylobates are also common, and are present in assemblages from all temperature ranges (Figure 3b). In contrast, bulliform flabellates (Neumann et al. 2019) are present in variable amounts throughout increases in temperature, but are relatively abundant in temperatures from around $750{ }^{\circ} \mathrm{C}$ (up to $2.2 \%$ in sample $\mathrm{O}-750$ ) as they comprise large dense and thereby robust epidermal appendages such as the acute bulbosus (trichomes and hairs) (ca. 11\%, samples C-800 and C-900). Other types of epidermal appendages, namely papillate are also noted in variable amounts, but commonly found in samples from higher temperatures into a lesser extent (up to $6.5 \%$ and 5.2, respectively) (Figure 3c). Elongates (dendritic, dentate, entire and sinuate) as well as multicellular phytoliths composed of elongates and other morphotypes (such as papillate, short cells and stomata) are also common in all the burning assemblages, 
although with some variations, but also remain relatively stable in samples around 800$900{ }^{\circ} \mathrm{C}$. Further, the multicelled elongate entire psilate (smooth) phytoliths are particularly abundant along with multicelled dendritics especially among the cow assemblages (up to 9.3\% and 7.6, respectively, sample C-900) (Figure 3d).

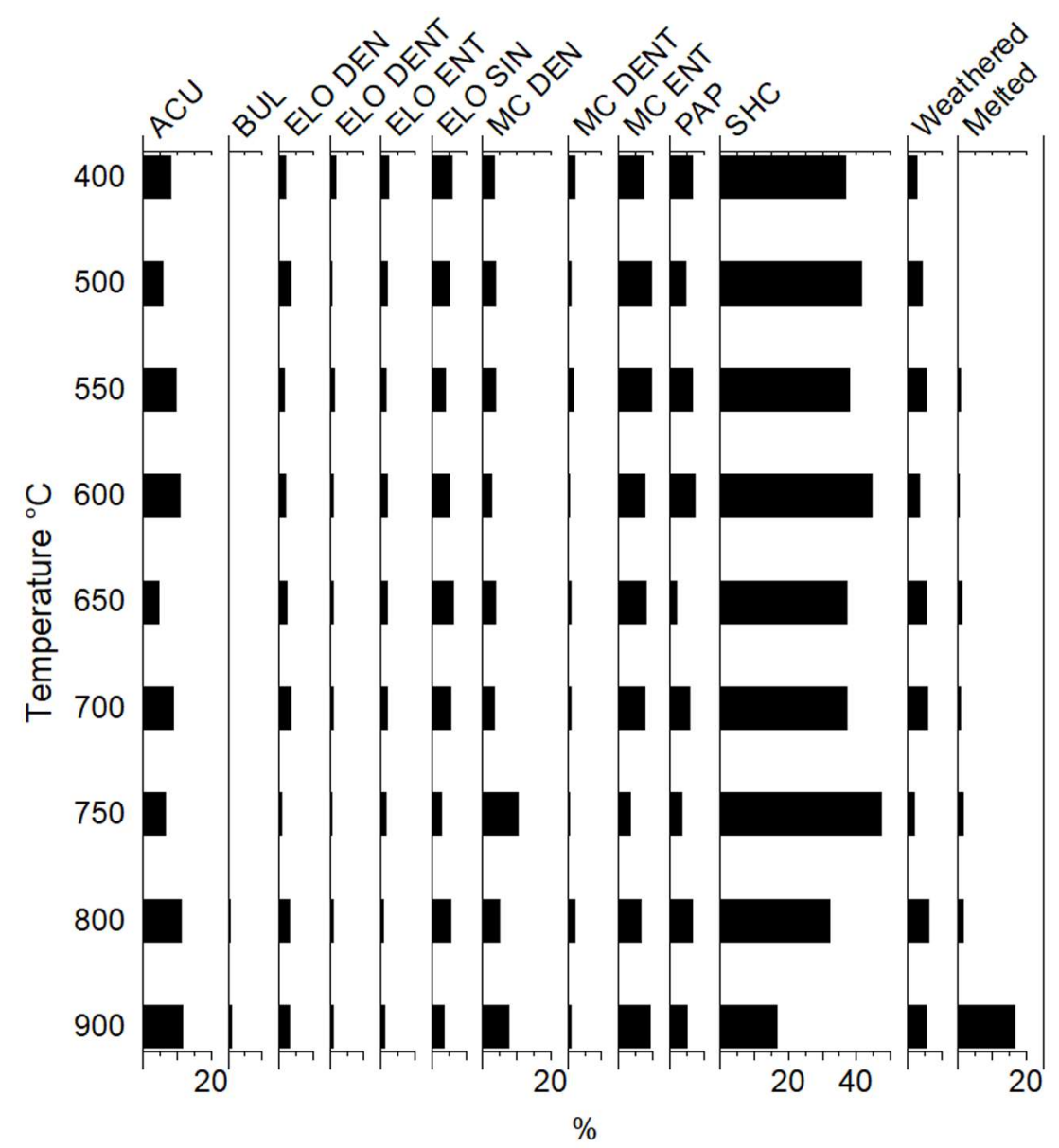

Figure 5: Relative abundances of main phytolith morphotypes obtained from cow experimental samples, with indication of weathering and melting percentages.

Although all of these variations and changes in abundances are relative, it is clear that not all phytolith morphotypes seem to be affected in the same way by heating. This is especially true for the grass short cell morphologies that become less abundant with increased temperatures of around $800-900{ }^{\circ} \mathrm{C}$.

Changes in morphotype composition have been previously reported by studying the effect of partial dissolution on the stability of different phytolith morphotypes produced by several modern plant species (Cabanes et al. 2011; Cabanes and ShahackGross 2015). In these dissolution experiments conducted on modern common wheat (Triticum aestivum), the changes in the relative amounts of phytolith morphotypes after 
dissolution varied considerably. In terms of relative abundance, the rondel short cells and the bulliforms were proportionately more abundant after dissolution, whereas the elongate psilate phytoliths in particular were less abundant (Cabanes et al. 2011). These dissolution experiments indicated that individual (single-celled) phytolith morphotypes have different stabilities. In addition, as a result of partial dissolution and abrasion some morphotypes may resemble others. As examples, dendritic elongates (long cells) may lose their decoration and become surface etched and pitted during diagenesis, and as a result could be mistakenly identified as dentate (echinate) phytoliths.

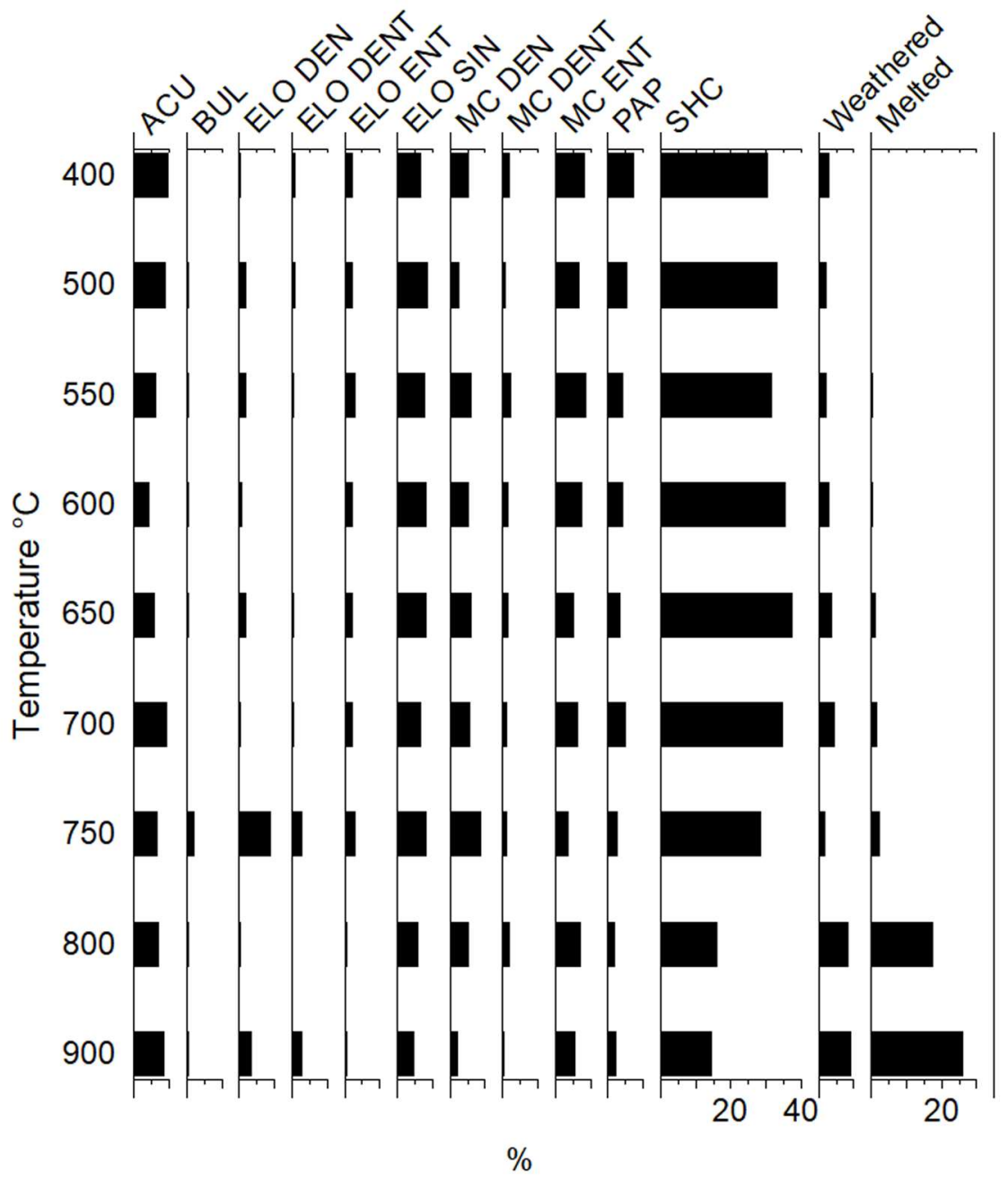

Figure 6: Relative abundances of main phytolith morphotypes obtained from sheep/ goat experimental samples, with indication of weathering and melting percentages.

Significantly, our heating experiments indicate that changes in phytolith morphotypes affect the type and rates of alteration due to heating, although there is not always a direct correlation as some are more susceptible to dissolution than effects of heat, for example. In the current experiments both decorated elongates (dendritic, 
dentate), as well as the sinuate and entire elongates are present in variable proportions, as well as their multicelled forms, but appear to be relatively resistant to temperatures as high as $800-900{ }^{\circ} \mathrm{C}$, and preserve their distinctive decorations, in contrast to the dissolution experiments that point to the loss of decoration. Further, in the present study the grass short cell rondel type phytoliths are found to become less stable under heating, while they are particularly resistant after chemical dissolution.

According to the above reported experimental records, it has been suggested that one of the factors that determines the impact of differential dissolution on the stability and preservation of phytoliths is the geometric surface to bulk ratio of individual phytoliths, which is tightly related to morphotype shape and size (Cabanes and Shahack-Gross 2015). It is well established that phytoliths vary in their morphology, but they also vary in their chemistry, and here again phytoliths with variable chemistries might be expected to degrade or to be affected at different rates (Hodson 2018). According to Hodson (2019) there are two main types of phytoliths, the cell wall types which are formed on a carbohydrate matrix with considerably higher carbon concentrations than the cell lumen types which are not. Although little work has been devoted to determining which phytoliths are cell wall types, a survey of transmission and scanning electron microscopy to establish which phytoliths are cell wall phytoliths, indicates that the acute bulbosus (trichomes and other hairs), as well as the wall protrusion of papillate are certainly cell wall types, whereas certain elongate phytoliths develop on a secondary cell wall to almost fill the lumen and silica is then deposited on them (see Figure 1 in Hodson 2019). In the current experimental work, all of these phytolith morphologies persist at temperatures as high as $900^{\circ} \mathrm{C}$, particularly elongate lumen type phytoliths rather than short cells. These variations in morphotype composition and the occurrence of the melting therefore may relate both to where phytoliths are produced and their roles within the plant anatomy, as well as the chemistry of the phytoliths. This may explain therefore how short cell phytoliths appear relatively less stable with increasing heating in contrast to the lumen type elongate morphotypes. Further work is needed to determine whether the degradation of cell wall phytoliths is greater than that of lumen phytoliths in experimental situations (Hodson 2019), as these factors could critically influence the representation and interpretation of phytolith results in the archaeological record.

\subsection{Dung spherulites results and taphonomic considerations}


For each material and temperature combination, the quantities of dung spherulites are presented as average numbers in $1 \mathrm{~g}$ of ashed dung material both in oxidising and in reducing heating conditions (Table 3). The average percentages of total numbers of spherulites were recorded both for 'normal' or 'darkened' following the classification standards defined by Canti and Nicosia (2018). In the latter case, the darkening spread across almost the whole spherulite and covers half or more of the overall diameter with a small clear fringe left at the perimeter (Figure $3 \mathrm{e}-\mathrm{f}$ ). The authors define darkened spherulites by a distinctive internal structure characterised by very fine crystallinity and larger scale fracturing, and suggest that their formation may relate to organic matter loss and/or $\mathrm{CaCO}_{3}$ alteration produced by heating. For examples of whether spherulites meet the criteria for being recorded as darkened see Figure 7 in Canti and Nicosia (2018). Darkened spherulites have been reported in archaeological contexts, primarily related to burnt areas of penning activity in naturally sheltered sites such as caves and rockshelters (e.g. Brochier et al. 1992; Iaconis and Boschian 2007; Polo-Díaz 2014, 2016) as well as in built households and open areas as the result of the burning of dung as fuel for cooking and other uses, pointing to some insights into firing activity (e.g. Brochier 1993; Castel et al. 2008; Portillo et al. 2019, 2020).

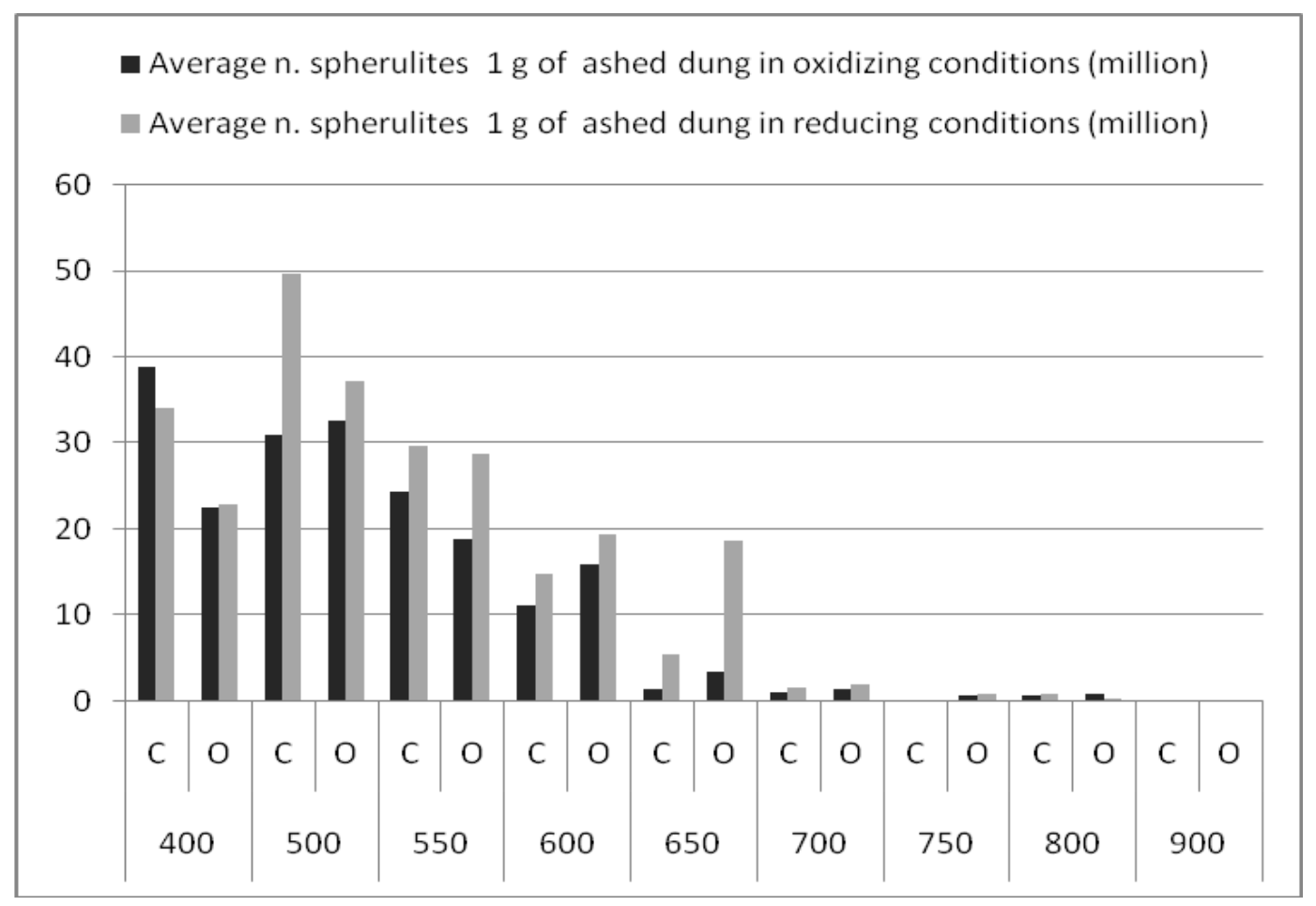

Figure 7: Plot showing average concentrations of dung spherulites obtained from oxidising $v s$. reducing conditions. 
Strong differences were noted in our experimental assemblages in dung spherulite abundance depending on the species of animal producers as well as temperature and combustion conditions (Figure 7). As expected, the most abundant assemblages of spherulites by far are present in residues from lower burning temperatures from 400 to $550{ }^{\circ} \mathrm{C}$ (with up to 49.7 million spherulites per gram of ashed dung, sample C-500, Table 3). Spherulites become less abundant with increased temperatures from around $600-650{ }^{\circ} \mathrm{C}$, particularly among the cow samples (between 1.2 and $19.4 \mathrm{~m}$ per $1 \mathrm{~g}$ of ashed dung), and are completely absent at $900{ }^{\circ} \mathrm{C}$ (Figure 7). When comparing the relative abundance of spherulites, in general, samples from combustion in reducing conditions had much greater numbers than the assemblages from oxidising conditions. In the latter case, spherulites were no longer visible and were replaced by $\mathrm{CaCO}_{3}$ neoformations, as noted by Canti and Nicosia (2018), particularly from temperatures of around $600-650^{\circ} \mathrm{C}$ and above. This pattern is argued to relate to the variability in the organic matter content and porosity of the dung pellets, as well as local air currents inside the furnace oven, which lead to unpredictable burn characteristics and patchy ignition (Canti and Nicosia, 2018).

The percentages of darkened spherulite distributions in the experimental assemblages also displayed a high degree of variability between the oxidising and the reducing combustion (Figure 8). In particular, in the key temperature range of around $550-700{ }^{\circ} \mathrm{C}$, high variability in darkened spherulite numbers was recorded. Therefore the oxidising conditions and the overheating due to ignition failed to produce darkened spherulites, especially from temperatures around $600-650{ }^{\circ} \mathrm{C}$ onwards. The only exceptions were samples O-600 and C-700, which displayed similar percentages under oxidising and reducing heating ( $\mathrm{ca}$. 27-29 and 6\% of the total of spherulites counted, respectively, Table 3). The results from reduced combustion show an increase in darkened spherulite proportions particularly from temperatures of $550{ }^{\circ} \mathrm{C}$ among the ovicaprine samples (15.7\%) with a maximum production at the range around 600-650 ${ }^{\circ} \mathrm{C}$ (samples O-600 and O-650, ca. 29-33\%, respectively). The number of darkened spherulites decreases at temperatures from $700{ }^{\circ} \mathrm{C}$ (sample O-700, 20.1\%), and almost disappears from $750{ }^{\circ} \mathrm{C}$ onwards (sample O-750, 1.6\%) (Figure 8). 


\begin{tabular}{|c|c|c|c|c|}
\hline $\begin{array}{l}\text { Material/ } \\
\text { temperature } \\
\left({ }^{\circ} \mathrm{C}\right)\end{array}$ & $\begin{array}{l}\text { Average } n . \\
\text { spherulites } 1 \mathrm{~g} \text { of } \\
\text { ashed dung in } \\
\text { oxidizing } \\
\text { conditions } \\
\text { (million) }\end{array}$ & $\begin{array}{l}\text { Average } n \text {. } \\
\text { spherulites } 1 \mathrm{~g} \text { of } \\
\text { ashed dung in } \\
\text { reducing } \\
\text { conditions } \\
\text { (million) }\end{array}$ & $\begin{array}{l}\text { Average } \\
\text { darkened } \\
\text { spherulites in } \\
\text { oxidizing } \\
\text { conditions (\%) }\end{array}$ & $\begin{array}{l}\text { Average } \\
\text { darkened } \\
\text { spherulites in } \\
\text { reducing } \\
\text { conditions (\%) }\end{array}$ \\
\hline C-400 & 38.8 & 34.1 & 0.7 & 0.6 \\
\hline $\mathrm{O}-400$ & 22.4 & 22.9 & 0.9 & 1.4 \\
\hline C-500 & 30.9 & 49.7 & 1.5 & 1.2 \\
\hline $\mathrm{O}-500$ & 32.5 & 37.2 & 6.8 & 8 \\
\hline C-550 & 24.3 & 29.7 & 9.7 & 4.4 \\
\hline O-550 & 18.8 & 28.7 & 24.6 & 15.7 \\
\hline C-600 & 11.1 & 14.8 & 0 & 10.3 \\
\hline O-600 & 15.8 & 19.4 & 27.8 & 29.1 \\
\hline C-650 & 1.2 & 5.3 & 0 & 6.5 \\
\hline O-650 & 3.3 & 18.6 & 0 & 33.3 \\
\hline C-700 & 0.9 & 1.5 & 6.5 & 6.9 \\
\hline O-700 & 1.2 & 1.9 & 0 & 20.1 \\
\hline C-750 & 0 & 0 & 0 & 0 \\
\hline O-750 & 0.5 & 0.7 & 0 & 1.6 \\
\hline C-800 & 0.5 & 0.7 & 0 & 0 \\
\hline O-800 & 0.8 & 0.2 & 0 & 0 \\
\hline C-900 & 0 & 0 & 0 & 0 \\
\hline O-900 & 0 & 0 & 0 & 0 \\
\hline
\end{tabular}

Table 3: Quantities of dung spherulites in experimental samples. C: cow, O: ovicaprine (sheep/ goat).

These results are consistent with previously reported records obtained from the combustion of sheep and goat pellets under reduction conditions carried out by Canti and Nicosia (2018), where the maximum recorded number of darkened spherulites in their experiments was at $600{ }^{\circ} \mathrm{C}$ and pointed to production between $500-700{ }^{\circ} \mathrm{C}$. The current study shows a significant increase of darkened spherulites at $550{ }^{\circ} \mathrm{C}$ and that the greatest amounts of these are reached from temperature ranges around $650{ }^{\circ} \mathrm{C}$ in reducing conditions. This study also confirms that high percentages of darkened spherulites (around $20-30 \%$ at $600{ }^{\circ} \mathrm{C}$ for 4 hours under reduction) are common within sheep and goat dung pellets, whereas cattle dung displayed relatively lower proportions in the same heating conditions, in which only up to $10 \%$ become darkened. This pattern is also associated with lower total spherulite numbers with increasing heating, and here again therefore may relate to the organic composition and porosity of the dung pellets, 
as cattle dung may be comparatively more fibrous and porous than in sheep and goat dung (Brönnimann et al. 2017), as well as to the gaseous exchange inside the furnace oven particularly in the case of oxidative heating with unpredictable burning conditions pointing towards spherulite decrease and complete loss.

Although most of the main processes of spherulite formation, abundance and taphonomy are becoming better understood, including the darkening process in ruminant dung under controlled-laboratory conditions (Brochier et al. 1992; Brochier 2002; Canti 1998, 1999; Korstanje et al. 2002; Shahack-Gross 2011; Canti and Brochier 2017; Canti and Nicosia 2018), the potential variations in relation to ecological and seasonal variability in dietary practices as well as sex/age-based aspects, have not been yet fully investigated. Further work currently being carried out includes assessing the variability in dung signatures according to seasonality and grazing/foddering patterns for a range of herd animals, as well as a result of exposure to fire under open-air conditions in experimental situations.

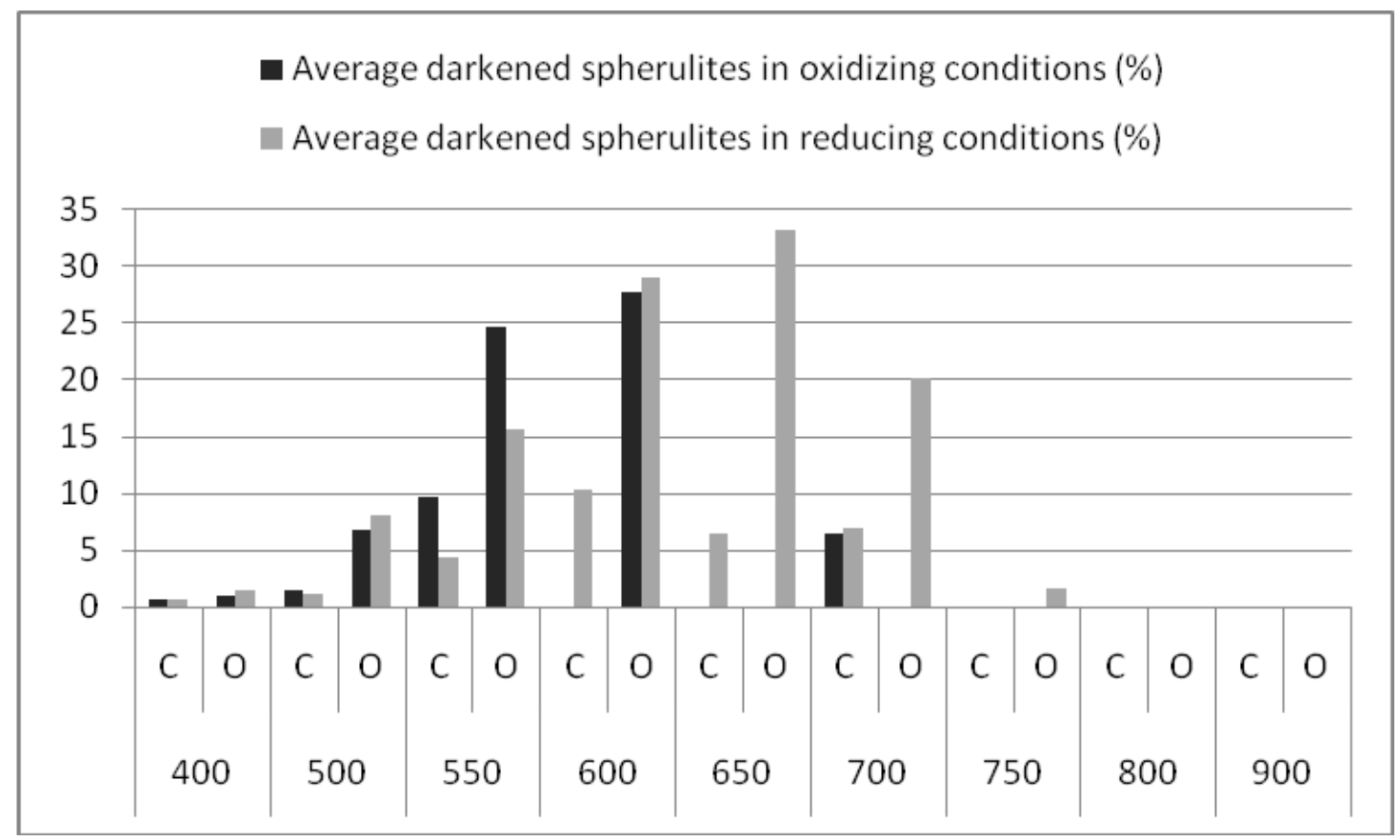

Figure 8: Plot showing average concentrations of darkened spherulites obtained from oxidising $v s$. reducing conditions. 


\section{Conclusions}

This ethnoarchaeological and experimental work contributes to our understanding of the effects of heating (burning) on phytolith morphotype and dung spherulite characteristics and taphonomy, which have critical implications for the interpretation of microfossil dung assemblages in archaeological contexts especially from the corralling and domestication of herd animals and the use of dung as fuel. The ethnoarchaeological research provided key information on parameters such as environment, animal ecology, grazing and foddering patterns and dung origin.

The experimental observations on the impact of increased heating and higher temperature combustion has implications for the durability and preservation of these microfossils that are excreted with dung, which are still under-studied. Integrated ethnoarchaeological and experimental research therefore is providing new information on the representation of these key microfossils in archaeological deposits and the understanding of formation and taphonomic processes.

The phytolith results point towards a clear association between a reduction in abundance and increase in melted morphologies particularly from the temperature range of ca. $800-900{ }^{\circ} \mathrm{C}$. At these temperatures melted phytoliths become completely deformed and display characteristics ranging from slightly bubbled surfaces through to vesicular and sinuous completely opaque morphologies which can no longer be assigned to specific morphotypes. This morphological analysis demonstrates that not all phytolith morphotypes seem to be affected in the same way by heating, and this is especially true for the grass short cells that appear less stable with increasing temperatures of around $800-900{ }^{\circ} \mathrm{C}$. In contrast, the elongate decorated (dentate, dendritic) as well as the elongate sinuate and entire (psilate) phytoliths remain relatively stable with increasing heating. We propose that the variations in the representation of different morphotypes and the occurrence of melted phytoliths may therefore be related. Other factors affecting the composition of phytolith assemblages and the effects of heat on these include: variations in plant selection by animal dung producers or human manipulation of fodder due to differences in the nature and diversity of environment, seasonality and dietary habits; the location and role of phytoliths in the anatomy of the plants ingested; and phytolith chemistry, as certain lumen type phytoliths (Hodson 2019) appear to be relatively more stable than short cells with increased heating. Further work is therefore 
needed to establish which phytoliths occur in cell walls or lumen types, and whether the degradation of cell wall phytoliths is greater than that of lumen morphotypes in controlled experimental conditions.

This experimental work further supports previous observations that dung spherulite darkening occurs in reducing conditions where the combustion gases are constrained and temperatures are within a range between 500 and $700{ }^{\circ} \mathrm{C}$, particularly from $550^{\circ} \mathrm{C}$ onwards, with a maximum production at $650{ }^{\circ} \mathrm{C}$. This is especially evident for sheep and goat dung pellets, as reported in previous experimental work (Canti and Nicosia 2018), where around $20-30 \%$ became darkened. Further, the present study shows that the cattle dung pellets under the same heating conditions also produce darkened spherulites, but to a lesser extent, with no more than about $10 \%$. This pattern therefore relates to the differential organic composition and porosity of the dung pellets, which are commonly more fibrous and porous in cattle than in sheep and goat, at least in the case of the oxidising heating. Although many details need further integrated ethnoarchaeological and experimental work to be more fully understood, the reported work provides comparative records on the variability in these microfossils that are excreted with dung, as well on the impact of burning, in addition to fundamental information on a range of formation processes and taphonomic aspects which are critical for interpreting the archaeological record.

\section{Acknowledgments}

This research was conducted within the framework of the MICROARCHEODUNG and the Central Zagros Archaeological Project (CZAP). The first author's work has been funded by the European Union's MICROARCHEODUNG project. The project has received funding from the EU Horizon 2020 research and innovation program under the Marie Sklodowska-Curie grant agreement No H2020-MSCA-IF-2015-702529. GA's work has been supported by an University of Reading Undergraduate Research Opportunities Programme fellowship supervised by MP and WM. KD's research was supported by an AHRC South West and Wales Doctoral Training Partnership PhD studentship and placement.

We are very grateful to all of the CZAP team members for their support and helpful discussions, as well as to the Sulaimaniyah Directorate of Antiquities and Heritage and its Director Kamal Rasheed Raheem for permission to export samples and helpful 
support. Special thanks are due to the families of Bestansur that welcomed us and other CZAP team members into their homes and provided key information for this research.

\section{Funding}

This work was supported by EU: [Grant Number H2020-MSCA -IF-2015-702529].

\section{Notes on contributors}

Dr Marta Portillo was a Marie Sklodowska Curie Fellow at the University of Reading. She is an environmental archaeologist specialised in phytoliths and calcitic microfossils in integration with geoarchaeological methods, as well as with experimental and ethnoarchaeological approaches. Her field of expertise investigates human-environment interactions and cultural, economic and technological innovations in the Western Mediterranean and the Near East. She serves at the board of the International Phytolith Society (IPS).

Kate Dudgeon is a $\mathrm{PhD}$ student at the University of Reading with an $\mathrm{MSc}$ in Environmental Archaeology. Her research focuses on the investigation of plant-use during the Epipalaeolithic and Neolithic in the Near East, primarily through the analysis of phytoliths and integrated with other environmental archaeological techniques to better understand human-environments.

Georgia Allistone was a UROP Fellow from the Undergraduate Research Opportunities Programme at the Department of Archaeology, University of Reading. She took part in the UROP Placement 'Human-animal interactions in early sedentary and urban societies in the Near East: phytolith and calcitic microfossil analysis of livestock dung'.

Kamal Raeuf Aziz graduated in Archaeology from the University of Erbil, in the Kurdistan Regional Government of Iraq. He is a staff member of the Sulaimani Directorate of Antiquities and Heritage, Sulaimani, Kurdistan Regional Government. $\mathrm{He}$ is a key member of many international teams active in this region.

Dr Wendy Matthews is Associate Professor in Archaeology at the University of Reading. She is Co-Director of the Central Zagros Archaeological Project and a specialist in micromorphology, integrated archaeobotany and early agriculture and urbanism. Her interdisciplinary research interests are in the built environment and sustainability from the origins of agriculture to today. 


\section{ORCID}

Marta Portillo http://orcid.org/0000-0002-2703-031X

Kate Dudgeon https://orcid.org/0000-0002-1585-9251

\section{References}

Albert, R. M., and S. Weiner. 2001. "Study of phytoliths in prehistoric ash layers from Kebara and Tabun caves using a quantitative approach." In Phytoliths: Applications in Earth Sciences and Human History, edited by J. D. Meunier and F. Colin, 251-266. Lisse: Balkema.

Albert, R. M., J. A. Ruiz, and A. Sans. 2016. "PhytCore ODB: A New Tool to Improve Efficiency in the Management and Exchange of Information on Phytoliths." Journal of Archaeological Science 68: 98-105.

Albert, R. M., R. Shahack-Gross, D. Cabanes, A. Gilboa, S. Lev-Yadun, M. Portillo, I. Sharon, E. Boaretto, and S. Weiner. 2008. "Phytolith-rich Layers from the Late Bronze and Iron Ages at Tel Dor (Israel): Mode of Formation and Archaeological Significance.” Journal of Archaeological Science 35 (1): 57-75.

Anderson, S., and F. Ertug-Yaras. 1998. "Fuel fodder and faeces: an ethnographic and botanical study of dung fuel use in central Anatolia". Environmental Archaeology 1: 99-110.

Bartoli, F., and L. P. Wilding. 1980. "Dissolution of biogenic opal as a function of its physical and chemical-properties". Soil Science Society of America Proceedings 44: 873-878.

Bendrey, R., J. Whitlam, and S. Elliott. 2013. "Ethnoarchaeological research in Iraqi Kurdistan". Association for Environmental Archaeology Newsletter 122: 3-4.

Bendrey, R., J. Whitlam, S. Elliott, K. Rauf Aziz, R. Matthews and W. Matthews. 2016. "'Seasonal rhythms' of a rural Kurdish village: ethnozooarchaeological research in Bestansur, Iraq." In People with Animals. Perspectives and Studies in Ethnozooarchaeology, edited by L. G. Broderick, 42-56. Oxford: Oxbow Books.

Brochier, J. E., P. Villa, M. Giacomarra, and A. Tagliacozzo. 1992. "Shepherds and sediments: Geo-ethnoarchaeology of pastoral sites." Journal of Anthropological Archaeology 11 (1): 47-102.

Brochier, J. E. 1993. "Çayönü Tepesi. Domestication, rythmes et environment au PPNB”. Paléorient 19: 39-49.

Brochier, J. E. 2002. "Les sédiments anthropiques. Méthodes d'étude et perspectives." In Géologie de la Préhistoire: méthodes, techniques, applications, edited by J.-C. Miskovsky, 453-477. Paris: Géopré Éditions. 
Brönnimann, D., Ismail-Meyer, K., Rentzel, P., Pümpin, C., and L. Lisá. 2017. "Excrements of herbivores". In: Archaeological Soil and Sediment Micromorphology, edited by C. Nicosia and G. Stoops, 55-65. Oxford: John Wiley and Sons Ltd.

Brown, D. A. 1984. "Prospects and limits of a phytolith key for grasses in the central United States." Journal of Archaeological Science 11 (4): 345-368.

Cabanes, D., and R. Shahack-Gross. 2015. "Understanding fossil phytolith preservation: the role of partial dissolution in paleoecology and archaeology." PLOS ONE 10 (5): $\mathrm{e} 0125532$.

Cabanes, D., S. Weiner, and R. Shahack-Gross. 2011. "Stability of phytoliths in the archaeological record: a dissolution study of modern and fossil phytoliths." Journal of Archaeological Science 38: 2480-2490.

Cabanes, D., F. Burjachs, I. Expósito, A. Rodríguez, E. Allué, I. Euba, and J. M. Vergès. 2009. "Formation processes through archaeobotanical remains: The case of the Bronze Age levels in El Mirador cave, Sierra de Atapuerca, Spain." Quaternary International 193: 160-173.

Canti, M. G. 1998. "The micromorphological identification of faecal spherulites from archaeological and modern materials." Journal of Archaeological Science 25 (5): 43544.

Canti, M. G. 1999. "The production and preservation of faecal spherulites: animals, environment and taphonomy." Journal of Archaeological Science 26 (3): 251-258.

Canti, M. G. 2003. "Aspects of the chemical and microscopic characteristics of plant ashes found in archaeological soils." CATENA 54 (3): 339-361.

Canti, M. G., and J. E. Brochier. 2017. "Faecal spherulites." In Archaeological Soil and Sediment Micromorphology, edited by C. Nicosia, and G. Stoops, 51-54. Chichester: John Wiley \& Sons.

Canti, M. G., and C. Nicosia. 2018. "Formation, morphology and interpretation of darkened faecal spherulites." Journal of Archaeological Science 89: 32-45.

Castel, C., D. Archambault, N. Awad, O. Barge, T. Boudier, J.E. Brochier, A. Cuny, S., Gondet, L. Herveux, F. Isnard, L. Martin, P. Quenet, S. Sanz, and E. Vila. 2008. "Rapport Préliminaire sur les Activités de la Mission Archéologique Franco Syrienne dans la Micro-région d'Al-Rawda (Shamiyeh): Quatrième et Cinquième Campagnes (2005 et 2006)". Akkadica 129: 5-54.

Delhon C., L. Martin, J. Argant, and S. Thiébault. 2008. "Shepherds and plants in the Alps: multi-proxy archaeobotanical analysis of neolithic dung from 'La Grande Rivoire' (Isère, France).” Journal of Archaeological Science 35: 2937-2952.

Delhon, C., D. Binder, P. Verdin, and A. Mazuy. 2020. "Phytoliths as a seasonality indicator? The example of the Neolithic site of Pendimoun, south-eastern France". Vegetation History and Archaeobotany 29: 229-240. 
Égüez, N., A. Zerboni, and B. Biagetti. 2018. "Microstratigraphic analysis on a modern central Saharan pastoral campsite. Ovicaprine pellets and stabling floors as ethnographic and archaeological referential data." Quaternary International 483: 180193.

Elliott, S., R. Bendrey, J. Whitlam, K. Rauf Aziz, and J. Evans. 2015. "Preliminary ethnoarchaeological research on modern animal husbandry in Bestansur, Iraqi Kurdistan: Integrating animal, plant and environmental data." Environmental Archaeology 20 (3): 283-303.

Friesem D. E. 2016. "Geo-ethnoarchaeology in action”. Journal of Archaeological Science 70: 145-157.

Gur-Arieh, S., E. Mintz, E. Boaretto, and R. Shahack-Gross. 2013. "An ethnoarchaeological study of cooking installations in rural Uzbekistan: development of a new method for identification of fuel sources." Journal of Archaeological Science 40: 4331-4347.

Gur-Arieh, S., R. Shahack-Gross, A. M. Maeir, G. Lehmann, L. A. Hitchcock, and E. Boaretto. 2014. "The taphonomy and preservation of wood and dung ashes found in archaeological cooking installations: case studies from Iron Age Israel." Journal of Archaeological Science 46: 50-67.

Hodson, M. J. 2018. "Phytoliths in Archaeology: Chemical Aspects" In Encyclopedia of Global Archaeology, edited by C. Smith. Berlin: Springer International Publishing AG. doi: 10.1007/978-3-319-51726-1_3250-1.

Hodson, M. J. 2019. "The Relative Importance of Cell Wall and Lumen Phytoliths in Carbon Sequestration in Soil: A Hypothesis." Frontiers in Earth Science 7 (167). doi: 10.3389/feart.2019.00167.

Hole, F. 1978. "Pastoral Nomadism in Western Iran." In Explorations in Ethnoarchaeology, edited by R. A. Gould, 127-167. Albuquerque: University of New Mexico Press.

Iaconis, M.A., and G. Boschian. 2007. "Geoarchaeology of the deposits of Grotta dei Piccioni and Grotta Sant'Angelo (Abruzzo, Central Italy), Atti della Societa Toscana di Scienze Naturali". Mem. Ser. A 112: 181-188.

Karkanas, P. 2006. "Late Neolithic household activities in marginal areas: the micromorphological evidence from the Kouveleiki caves, Peloponnese, Greece". Journal of Archaeological Science 33: 1628-1641.

Katz, O., D. Cabanes, S. Weiner, A. Maeir, E. Boaretto, and R. Shahack-Gross. 2010. "Rapid phytolith extraction for analysis of phytolith concentrations and assemblages during an excavation: An application at Tell es-Safi/Gath, Israel." Journal of Archaeological Science 37: 1557-1563. 
Korstanje, M. A. 2002. "Microfossils in camelid dung: Taphonomic considerations for the archaeological study of agriculture and pastoralism." In Biosphere to Lithosphere: New studies in vertebrate taphonomy, edited by T. O'Connor, 69-77. Oxford: Oxbow Books.

Kramer, C. 1979. "An archaeological view of a contemporary Kurdish village: domestic architecture, household size, and wealth." In Ethnoarchaeology: implications of Ethnography for Archaeology, edited by C. Kramer, 139-163. New York: Columbia University Press.

Kramer, C. 1982. Village Ethnoarchaeology: Rural Iran in Archaeological Perspective. New York: Academic Press.

Madella, M., A. Alexandre, and T. Ball. 2005. "International Code for Phytolith Nomenclature 1.0." Annals of Botany 96: 253-260.

Maran, A. and Z. Stevanovic. 2009. The Iraqi Kurdistan Environment: An Invitation to Discover. Belgrade: IK Consulting Engineers and ITSC Ltd.

Macphail, R. I. and G. M. Cruise. 2001. "The Soil Micromorphologist as Team Player. A multianalytical approach to the study of European microstratigraphy." In Earth Sciences and Archaeology, edited by P. Goldberg, V.T. Holliday, and C.R. Ferring, 241-268. New York: Springer.

Matthews, W. 2005. "Micromorphological and microstratigraphic traces of uses and concepts of space". In Inhabiting Çatalhöyük: Reports from the 1995-1999 Seasons, edited by Ian Hodder, 355-398. Cambridge: McDonald Institute and British Institute of Archaeology at Ankara.

Matthews, W. 2010. "Geoarchaeology and taphonomy of plant remains and microarchaeological residues in early urban environments in the Ancient Near East." Quaternary International 214 (1-2): 98-113.

Matthews, W. 2016. "Humans and fire: Changing relations in early agricultural and built environments in the Zagros, Iran, Iraq." The Anthropocene Review 3: 107-139.

Matthews, W., C. A. I. French, T. Lawrence, and D. Cutler. 1996. "Multiple surfaces: the micromorphology." In On the Surface: Çatalhöyük 1993-1995, edited by I. Hodder, 301-342. Cambridge: McDonald Institute for Archaeological Research and British Institute of Archaeology at Ankara.

Matthews, R., W. Matthews, K. R. Raheem, and K. R. Aziz. 2016. "Current investigations into the early Neolithic of the Zagros foothills of Iraqi Kurdistan" In The Archaeology of the Kurdistan Region of Iraq and Adjacent Regions, edited by K. Kopanias and J. MacGinnis, 219-228. Oxford: Archaeopress.

Matthews, R., W. Matthews, A. Richardson, K. R. Raheem, S. Walsh, K. R. Aziz, R. Bendrey, J. Whitlam, M. Charles, A. Bogaard, I. Iversen, D. Mudd, and S. Elliott. 2019. "The early Neolithic of Iraqi Kurdistan: current research at Bestansur, Shahrizor Plain”. Paléorient: 45 (2): 13-32. 
Matthews, R. J., W. Matthews, K. Rasheed Raheem, and A. Richardson (eds.) (2020a). The Early Neolithic of the Eastern Fertile Crescent. Excavations at Bestansur and Shimshara, Iraqi Kurdistan. CZAP Volume 2, 261-282. Oxford: Oxbow Books.

Matthews, W., A. Garcia-Suarez, M. Portillo, C. B. Speed, G. Allistone, I. Bull, J. Godleman, and M. J. Almond (2020b). "Integrated micro-analysis of the built environment and resource use: high-resolution microscopy and geochemical, mineralogical and biomolecular approaches." In The Early Neolithic of the Eastern Fertile Crescent. Excavations at Bestansur and Shimshara, Iraqi Kurdistan, edited by R. J. Matthews, W. Matthews, K. Rasheed Raheem, and A. Richardson. Oxford: Oxbow Books.

Miller, N. F. 1984. "The use of dung as fuel: an ethnographic example and an archaeological application". Paléorient 10: 71-79.

Mulholland, S.C., and Jr.G. Rapp. 1992. "A morphological clasification of grass silicabodies." In Phytolith Systematics: Emerging Issues, Advances in Archaeological and Museum Science, edited by G. Jr. Rapp, and S.C. Mulholland, 65-89. New York: Plenum Press.

Neumann, K., A. E. C. Strömberg, T. B. Ball, R. M. Albert, L. Vrydaghs, and L. ScottCummings (International Committee for Phytolith Taxonomy ICPT). 2019. "International Code for Phytolith Nomenclature (ICPN) 2.0". Annals of Botany 124 (2): 189-199.

Piperno, D. R. 1988. Phytolith analysis: an archaeological and geological perspective. San Diego: Academic Press.

Piperno, D. R. 2006. Phytoliths. A Comprehensive Guide for Archaeologists and Paleoecologists. Oxford: AltaMira Press.

Polo-Díaz, A., J. Martínez-Moreno, A. Benito-Calvo, and R. Mora. 2014. "Prehistoric herding facilities: site formation processes and archaeological dynamics in Cova Gran de Santa Linya (Southeastern Prepyrenees, Iberia)". Journal of Archaeological Science 41: 784-800.

Polo-Díaz, A., M. Eguíluz, M. Ruiz, S. Pérez, J. Mújika, R. M. Albert, and J. Fernández Eraso. 2016. "Management of residues and natural resources at San Cristóbal rockshelter: contribution of the characterization of chalcolithic agropastoral groups in the Iberian Peninsula." Quaternary International 414: 202-225.

Portillo, M., and W. Matthews. 2020. "Investigating use of space and human-animal interactions in agricultural built environments: the geo-ethnoarchaeology of livestock dung". In Proceedings of the 11th International Congress on the Archaeology of the Ancient Near East, edited by A. Otto, M. Herles and K. Kaniuth, 497-508. Wiesbaden: Harrassowitz Verlag. 
Portillo, M., R.M. Albert, and D.O. Henry. 2009. "Domestic Activities and Spatial Distribution in Ain Abū Nukhayla (Wadi Rum, Southern Jordan): The Use of Phytoliths and Spherulites Studies". Quaternary International 193: 174-183.

Portillo, M., S. Valenzuela, and R. M. Albert. 2012. "Domestic patterns in the Numidian site of Althiburos (northern Tunisia): The results from a combined study of animal bones, dung and plant remains." Quaternary International 275: 84-96.

Portillo, M., S. Kadowaki, Y. Nishiaki, and R. M. Albert. 2014. "Early Neolithic household behavior at Tell Seker al-Aheimar (Upper Khabur, Syria): a comparison to ethnoarchaeological study of phytoliths and dung spherulites." Journal of Archaeological Science 42: 107-118.

Portillo, M., M. C. Belarte, J. Ramon, N. Kallala, J. Sanmartí, and R. M. Albert. 2017. "An ethnoarchaeological study of livestock dung fuels from cooking installations in northern Tunisia." Quaternary International 431: 133-144.

Portillo, M, A. García-Suárez, A. Klimowicz, M. Z. Barański, and W. Matthews. 2019. "Animal penning and open area activity at Neolithic Çatalhöyük, Turkey". Journal of Anthropological Archaeology 56: 101106. doi.org/10.1016/j.jaa.2019.101106

Portillo, M., A. García-Suárez, and W. Matthews. 2020. "Livestock faecal indicators for animal management, penning, foddering and dung use in early agricultural built environments in the Konya Plain, Central Anatolia". Archaeological and Anthropological Sciences 12: 40. doi.org/10.1007/s12520-019-00988-0

Reddy, S. N. 1999. "Fueling the hearths in India: the role of dung in paleorthnobotanical Interpretation." Paléorient 24: 61-70.

Rosen, A. M. 1992. "Preliminary identification of silica skeletons from Near Eastern archaeological sites: an anatomical approach". In Phytolith Systematics edited by George Rapp and Susan C. Mulholland, 129-148. New York: Plenum Press.

Runge, F. 1998. "The effect of dry oxidation temperature $\left(500-800^{\circ} \mathrm{C}\right)$ and of natural corrosion on opal phytoliths." In Deuxième congrès international de recherche sur les phytolithes, edited by J. D. Meunier, F. Colin, and L. Faure-Denard, 73. Aix-enProvence: CEREGE.

Saed Ali, S. 2008. Geologija $i$ hidrogeologija arazurpiramagrun basena u oblasti sulejmanije, severoistoèni irak. Belgrade: Univerzitet u Beogradu Rudarsko-geoloki Fakultet.

Shahack-Gross, R. 2011. "Herbivorous livestock dung: formation, taphonomy, methods for identification, and archaeological significance." Journal of Archaeological Science 38 (2): 205-218.

Shahack-Gross, R., and I. Finkelstein. 2008. "Subsistence practices in an arid environment: a geoarchaeological investigation in an Iron Age site, the Negev Highlands, Israel.” Journal of Archaeological Science 35: 965-982. 
Shahack-Gross, R., F. Marshall, and S. Weiner, 2003. "Geo-Ethnoarchaeology of Pastoral sites: the identification of livestock enclosures in Abandonned Maasai Settlements." Journal of Archaeological Science 30: 439-459.

Shahack-Gross, R., F. Marshall, K. Ryan, and S. Weiner. 2004. "Reconstruction of spatial organization in abandoned Maasai settlements: implications for site structure in the Pastoral Neolithic of East Africa". Journal of Archaeological Science 31 (10): $1395-1411$.

Shahack-Gross, R., R. M. Albert, A. Gilboa, O. Nagar-Hilman, I. Sharon, and S. Weiner. 2005. "Geoarchaeology in an urban context: the uses of space in a Phoenician monumental building at Tel Dor (Israel)." Journal of Archaeological Science 32: 14171431.

Sillar, B. 2000. "Dung by preference: the choice of fuel as an example of how Andean pottery production is embedded within wider technical, social, and economic practices." Archaeometry 42: 43-60.

Spengler, R. N. 2019. "Dung burning in the archaeobotanical record of West Asia: where are we now?" Vegetation History and Archaeobotany 28: 215-227.

Tsartsidou, G., S. Lev-Yadun, R. M. Albert, A. M. Rosen, N. Efstratiou, and S. Weiner. 2007. "The phytolith archaeological record: strengths and weaknesses evaluated based on a quantitative modern reference collection from Greece". Journal of Archaeological Science 34 (8): 1262-1275.

Tsartsidou, G., S. Lev-Yadun, N. Efstratiou, and S. Weiner. 2008. "Ethnoarchaeological study of phytolith assemblages from an agro-pastoral village in Northern Greece (Sarakini): development and application of a Phytolith Difference Index". Journal of Archaeological Science 35 (3): 600-613.

Twiss, P. C. 1992. "Predicted world distribution of C3 and C4 grass phytoliths." In Phytolith Systematics, edited by G. Rapp and S. C. Mulholland, 113-128. New York: Plenum Press.

Twiss, P. C., C. E. Suess, and R. M. Smith. 1969. "Morphological classification of grass phytoliths". Soil Science Society of America Proceedings 33: 109-115.

Vos, D., E. Jenkins, and C. Palmer. 2003. "A dual geochemical-phytolith methodology for studying activity areas in ephemeral sites: Insights from an ethnographic case study from Jordan”. Geoarchaeology 33: 680-694.

Vrydaghs, L., Y. Devos, and A. Petö. 2017. "Opal Phytoliths.” In Archaeological Soil and Sediments Micromorphology, edited by C. Nicosia and G. Stoops, 155-164. Oxford: Wiley.

Watson, P. J. 1979. Archaeological Ethnography in Western Iran. Tucson: Univeristy of Arizona Press for the Wenner-Gren Foundation for Anthropological Research Inc. 
Wilding, L.P., and L.R. Drees. 1974. "Contributions of forest opal and associated crystalline phases to fine silt and clay fractions of soils". Clays Clay Miner, 22: 295306.

Wu, Y., Ch. Wang, and D. V. Hill. 2012. "The Transformation of Phytolith Morphology as the Result of their Exposure to High Temperature." Microscopy Research and Technique 75: 852-855.

Wu, Y., Y. Yang, H. Wang, and Ch. Wang. 2014. "The effects of chemical composition and distribution on the preservation of phytolith morphology." Applied Physics A 114 (2): 503-507.

Zapata, L., L. Peña-Chocarro, J. J. Ibáñez Estévez, and J. E. González Urquijo. 2003. "Ethnoarchaeology in the Moroccan Jebala (Western Rif): Wood and dung as fuel". Africa Praehistorica 15: 163-175. 